\title{
Management Intensification of Hay Meadows and Fruit Orchards Alters Soil Macro- Invertebrate Communities Differently
}

\author{
Elia Guariento ${ }^{1,2, *(\mathbb{D})}$, Filippo Colla ${ }^{1,2}$, Michael Steinwandter ${ }^{1} \mathbb{D}$, Julia Plunger ${ }^{1}$, \\ Ulrike Tappeiner $^{1,2}$ and Julia Seeber ${ }^{1,2}$ \\ 1 Institute for Alpine Environment, Eurac Research, Viale Druso 1, 39100 Bozen/Bolzano, Italy; \\ filippo.colla@eurac.edu (F.C.); michael.steinwandter@eurac.edu (M.S.); julia.plunger@eurac.edu (J.P.); \\ ulrike.tappeiner@eurac.edu (U.T.); julia.seeber@eurac.edu (J.S.) \\ 2 Department of Ecology, University of Innsbruck, Technikerstrasse 25/Sternwartestrasse 15, \\ 6020 Innsbruck, Austria \\ * Correspondence: elia.guariento@eurac.edu; Tel.: +49-0471-055-298
}

Received: 17 April 2020; Accepted: 22 May 2020; Published: 28 May 2020

\begin{abstract}
Land-use changes and especially management intensification currently pose a major threat to biodiversity both on and beneath the soil surface. With a comparative approach, we investigated how management intensity in orchards and meadows influences soil macro-invertebrate communities in a North-Italian Alpine region. We compared soil fauna assemblies from traditional low-input sites with respective intensively managed ones. As expected, the taxonomical richness and diversity were lower in both intensive management types. Extensive management of both types revealed similar communities, while intensification led to substantial differences between management types. From these results, we conclude that intensification of agricultural practices severely alters the soil fauna community and biodiversity in general, however, the direction of these changes is governed by the management type. In our view, extensive management, traditional for mountain areas, favors soil fauna communities that have adapted over a long time and can thus be viewed as a sustainable reference condition for new production systems that consider the protection of soil diversity in order to conserve essential ecosystem functions.
\end{abstract}

Keywords: traditional management; soil biodiversity; sustainable agriculture; management intensity; South Tyrol; mountain agriculture

\section{Introduction}

The industrialization of agriculture characterized by high input practices in most cases increases production but severely hampers the overall diversity of life that inhabits managed areas from single fields to whole landscapes [1,2]. This change towards more intensive management is currently causing major losses of biodiversity on a global scale [3,4]. On the other hand, there is a growing acknowledgment that biodiversity sustains the agricultural production with several direct and indirect ecosystem services, from supporting pollination and pest control [5] to the provision of long-term stability and the maintenance of ecosystem functions [6,7]. Consequently, biodiversity loss and the resulting possible absence of ecosystem services are considered to be so profound that they pose a threat to the current and future food provisioning system [8]. Thus, developing sustainable agricultural practices that conserve biodiversity and secure the provision of food in the long run, has become a global goal and challenge [8-11]. It is of major interest (1) to describe the state of production systems that might sustain a major proportion of biodiversity and are considered sustainable long-term and 
(2) to investigate the changes caused by management intensification to subsequently identify and understand the potential causes of these changes.

Soils are of vital importance for agriculture by providing for the essential ecosystem functions and services, such as carbon sequestration, water regulation, soil structure alteration, nutrient cycling, and retention $[12,13]$. The current global loss of biodiversity is apparently happening also for soil organisms in concomitance to the general soil degradation, posing a threat to important services which soils and its inhabitants provide $[14,15]$. Changing land-use practices and intensifying the management contribute to the current reduction in soil biodiversity [16,17]. Recent studies on soil invertebrates found that the soil community reacts to management intensification by reducing average body size, by shortening its trophic chain length and by reducing the overall diversity, thus influencing ecosystem processes and soil quality [17-22]. However, agricultural production depends directly on the soil quality [23] and this quality is directly linked to soil inhabitants [24]. Especially macro-invertebrates are well-suited bioindicators, linked to most soil ecosystem functions and services [25], sensible to both anthropogenic and environmental changes [26] and commonly used to evaluate the general soil quality [21,27].

The present study aims to investigate the soil communities of two production systems, hay meadows and fruit orchards, both characterized by traditional, extensive, and sustainable production systems and to evaluate changes in community structures after the intensification of these management practices.

More specifically, we test (1) if taxa richness and diversity decline from extensive to intensive management; (2) if meadows and orchards harbor a different community of soil macro-invertebrates and (3) if intensification similarly influences the community of both management types.

We expect differences in the soil community between the two habitat types (meadows and orchards) since the presence of trees is known to significantly alter both biotic and abiotic characteristics in their surroundings [28]. Further, we expect that the intensification of both practices results in similar constraints for the soil community, leading to similar and less diverse community compositions [17].

\section{Materials and Methods}

The study region (South Tyrol, Italy) is an Alpine region where agriculture is characterized by small farms, with orchards dominating the agricultural practice in the valley floors and hay meadows on intermediate elevations [29]. Hay meadows we defined as managed grasslands mowed for hay production at least once a year, with no or limited pasturing occurring in late summer and autumn after the hay harvest.

The extensive and traditional management form of both practices was locally performed for several hundred and up to thousands of years and is expected to harbor a specialized and diverse community $[30,31]$. Both production types underwent land-use changes (intensification or abandonment) over the course of the last decades and intensive management has broadly replaced the extensive form, especially on lower elevations [32].

A full factorial design was chosen with a set of four fields in six different locations (Figure 1). Each location comprised two meadows and two orchards, each with intensive and extensive management; overall, 24 fields were investigated. The selection of the locations was limited by the requirement that all four management types had to be close together (based on geographical information systems). The single fields were selected on-site based both on the farmer's statement regarding the management intensity and a brief inspection of the vegetation cover. Data concerning the mowing frequencies, manuring type and frequency, grazing type, and intensity were compiled as precisely as possible (Table S1). With these parameters, a simplified version of the land-use index (LUI) following the procedure proposed by Blüthgen [33] and Fischer [34] was performed. The only difference from this approach concerned the use of manuring frequency rather than the amount of nitrogen used to fertilize since precise data could not be obtained for each field. Further, site parameters were recorded locally (coordinates, elevation, slope, exposition), while chemical parameters of soil 
samples (such as SOM, $\mathrm{pH}, \mathrm{C} / \mathrm{N}, \mathrm{N}$, and $\mathrm{P}$ content) were analyzed by a specialized laboratory at the Laimburg Research Center (South Tyrol). Physical parameters (soil texture) were analyzed using the automated PARIO system (meter group [35]) (for soil parameters and site characteristics see Table S1; for correlation among these factors see Figure S1). The soil samples for the chemical and physical analyses were collected in each field by taking six subsamples in 5-10 cm depth (the medium depth of the macrofauna samples) at least $10 \mathrm{~m}$ apart from each other (three in autumn 2018 and three in spring 2019 , at the same time of sampling of the soil fauna community). These six subsamples were mixed to receive one homogenized sample per field for further analyses.
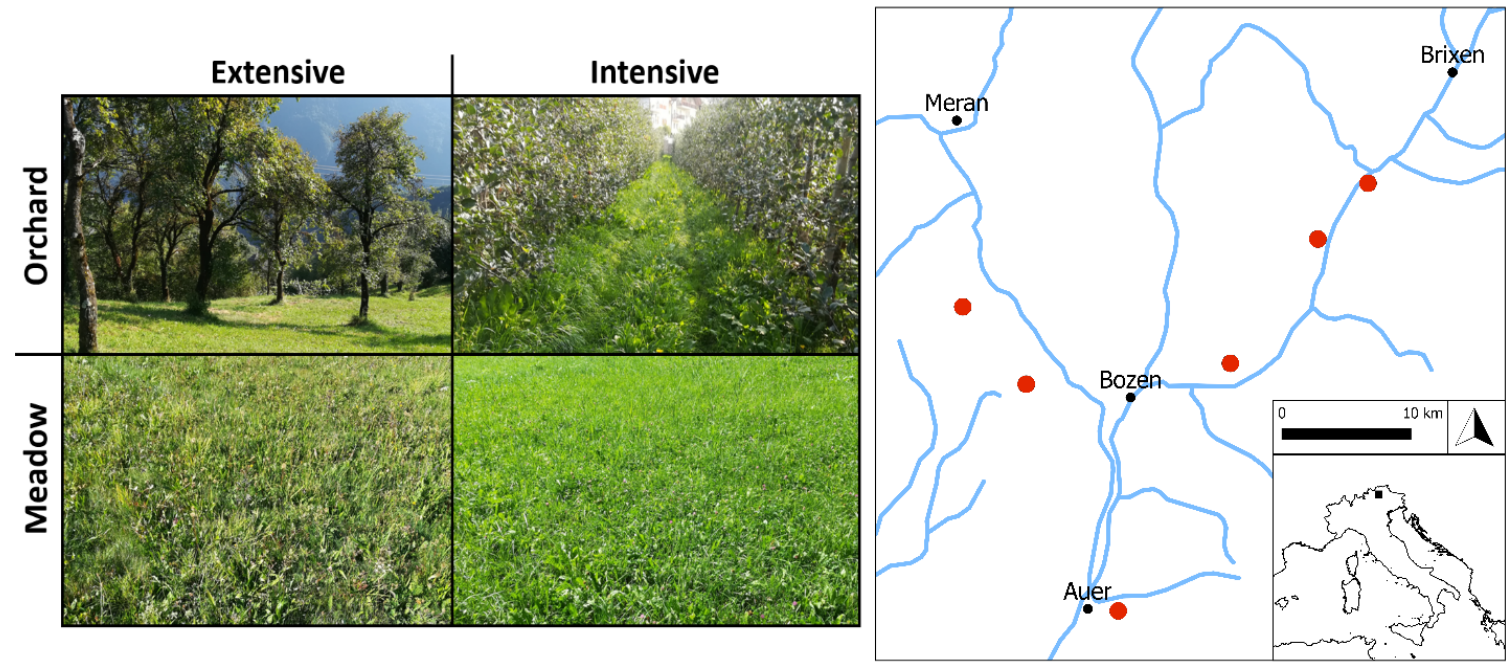

Figure 1. Schematic representation of the four differently managed field types located in each of the six sampling locations depicted in the map (red dots). The map shows a central excerpt from South Tyrol, the northernmost Province of Italy.

In total, 213 single soil core samples $(20 \times 20 \times 15 \mathrm{~cm}$ square frame) were collected at three different time points (autumn 2018, spring 2019, and autumn 2019) with three sub-replicates per field and date. The three sub-replicate samples were collected within a minimum of $10 \mathrm{~m}$ distance from each other and in orchards within a distance of one to two meters from the tree base (e.g., for intensive apple orchards in the middle of the driveway). We added an additional sampling in autumn 2019 (except for one single field where the access was not granted by the farmer), since the very dry summer 2018 may have influenced the community composition in autumn 2018. The soil macro-invertebrates were extracted using a heat extractor (modified after [36]), quantified and identified to family level (except for Symphyla) using suitable identification keys [37-41] and following the taxonomic information of Fauna Europea Database [42]. For the ordination analysis, we treated adult and larval stages of beetles as different taxa since they differ functionally.

Sampling coverage was investigated for each single-season and field type using species accumulation curves based on the single soil core sample as sampling unites (INExT [43]; Figure S2). The three sub-replicates were then averaged to one single sample per sampling time and used as such for the following analysis (see the full community in Table S2). Taxon diversity is represented by the Shannon-Wiener diversity index (computed with function diversity in veGAN; [44]). For the statistical analysis of taxon richness and diversity, a linear mixed model with season and regions (nested in season) modeled as random factors was constructed. Scores were extracted with the function predict and used to generate boxplots. Further, a mixed-model constrained ordinations (function capscale in VEGAN; [44] using Bray-Curtis distances) were used to investigate the community composition changes and a PERMANOVA (function adonis in VEGAN; [44]) was used to verify if the field type centroids differ significantly. For these computations, the community matrix was reduced by excluding ants, for which the sampling methodology is not appropriate, they differ inlife history and occurrence. 
All variables were standardized. The season was modeled as a random factor to account for temporal autocorrelation and the region was modeled as a random factor nested within the season to account for spatial autocorrelation between the fields. We chose single factors to be tested in the constrained ordination, which (1) represented the site characteristics, the management intensity, the chemical and the physical soil properties, (2) did not correlate significantly with each other, and (3) had a priori expected effect on the soil community. We tested these factors with a permutation test upon the full model and only significant parameters were implemented in the final ordination. All computations and graphics were performed and generated using the statistical programming software $R$ [45]. Graphics were produced using the package GGPLOT2 [46], the correlation plot was generated using the package CORRPLOT [47].

\section{Results and Discussion}

Taxa richness (on average 18.5 \pm 4.9 SD in extensive meadows; $17.1 \pm 3.9$ SD in intensive meadows; $19.1 \pm 5.0 \mathrm{SD}$ in extensive orchards; $14.1 \pm 3.7 \mathrm{SD}$ in intensive orchards) as well as diversity (on average 2.33 $\pm 0.27 \mathrm{SD}$ in extensive meadows; $2.18 \pm 0.17 \mathrm{SD}$ in intensive meadows; $2.19 \pm 0.27 \mathrm{SD}$ in extensive orchards; $2.04 \pm 0.25 \mathrm{SD}$ in intensive orchards) was found to be significantly reduced under more intensive management in both meadows and orchards (Figure 2; Table 1). This result was expected and has already been shown for both soil $[16,17,20]$ and above ground organisms (e.g., $[4,30,48])$. Nevertheless, this confirms the severe impact management intensification has on overall soil biodiversity also for the systems investigated in this study. Specifically, for meadows, there is already broad evidence that management intensification alters the soil community and its related functional aspect (e.g., [22,48]). For orchards, on the other hand, the literature is more sparse and inconsistent regarding the supported biodiversity and intensification effects, especially for soil fauna communities (but see $[49,50]$ ). Species accumulation curves depict an overall good coverage for each season and further confirm the low scoring of intensive orchards in comparison to extensive managed fields. Intensive meadows score on an intermediate position, due to a higher taxa richness in spring (Figure S2).
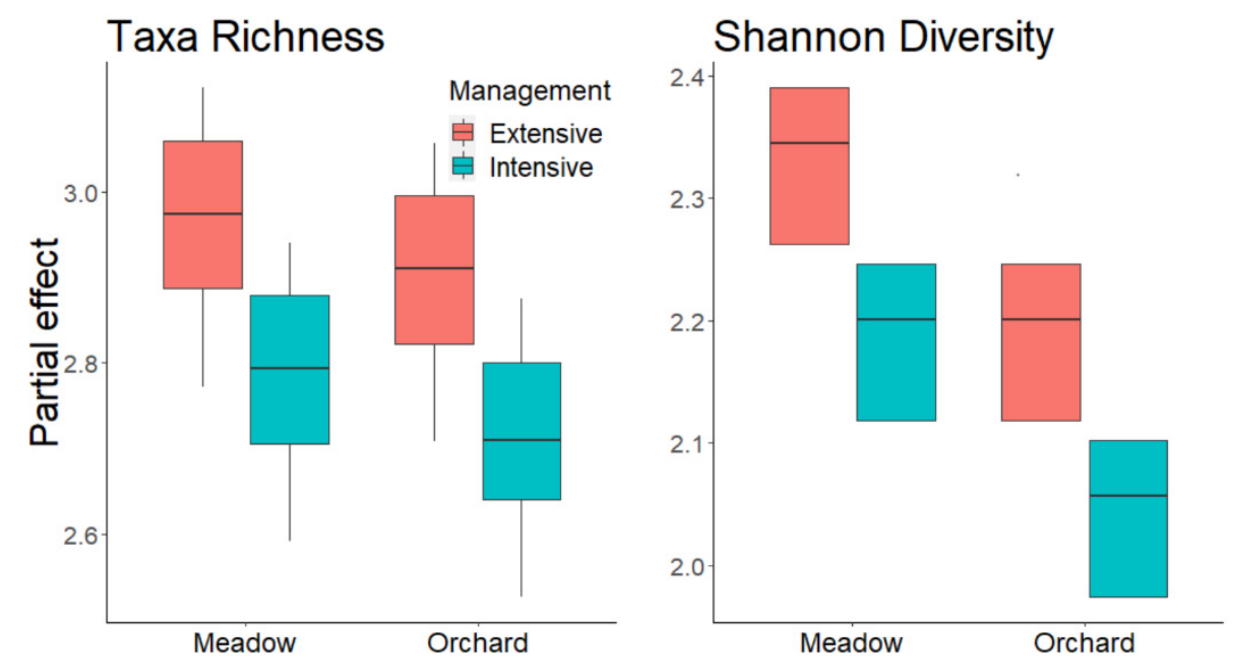

Figure 2. Boxplot of the partial effect of habitat (meadow and orchard) and management intensity (intensive and extensive) on taxa richness and diversity (Shannon diversity) $(n=18)$. The data was extracted from the linear mixed model accounting for the effect of region and season treated as random factors. Boxplot depicting the interquartile range (IQR between the $25 \%$ and the $75 \%$ ) and the median, whiskers extending 1.5 * the IQR. 
Table 1. Likelihood ratio test of linear mixed-model for taxa richness and diversity (Shannon diversity). Habitat (meadow vs. orchard) and management intensity (extensive vs. intensive) were tested separately. The region was implemented as a random factor nested in the season to account for both spatial and temporal autocorrelation.

\begin{tabular}{ccccc}
\hline Dimension & Factor & df. & $\mathbf{C h i}^{2}$ & $\boldsymbol{p}$ \\
\hline \multirow{2}{*}{ Richness } & Management & 1 & 9.85 & 0.002 \\
\cline { 2 - 5 } & Habitat & 1 & 1.52 & 0.283 \\
\hline \multirow{2}{*}{ Diversity } & Management & 1 & 6.03 & 0.014 \\
\cline { 2 - 5 } & Habitat & 1 & 5.98 & 0.014 \\
\hline
\end{tabular}

The community composition was overall significantly different between the four field types (PERMANOVA; 999 permutations: $F_{3,70}=2.169, p<0.001$ ). Further, a surprisingly similar community was found in the extensively managed fields (Figure 3). This was in part unexpected because of the significant role trees are known to exert on the soil community [28]. This similarity is probably due to both the similar land-use intensity (characterized by the factor land use index (LUI) after [33]) and the generally richer and more diverse soil community adapted to the traditional extensive practice. The rather clear separate plotting of the intensive fields both from the extensive ones and from each other further underlines the important effect of management intensification and type.

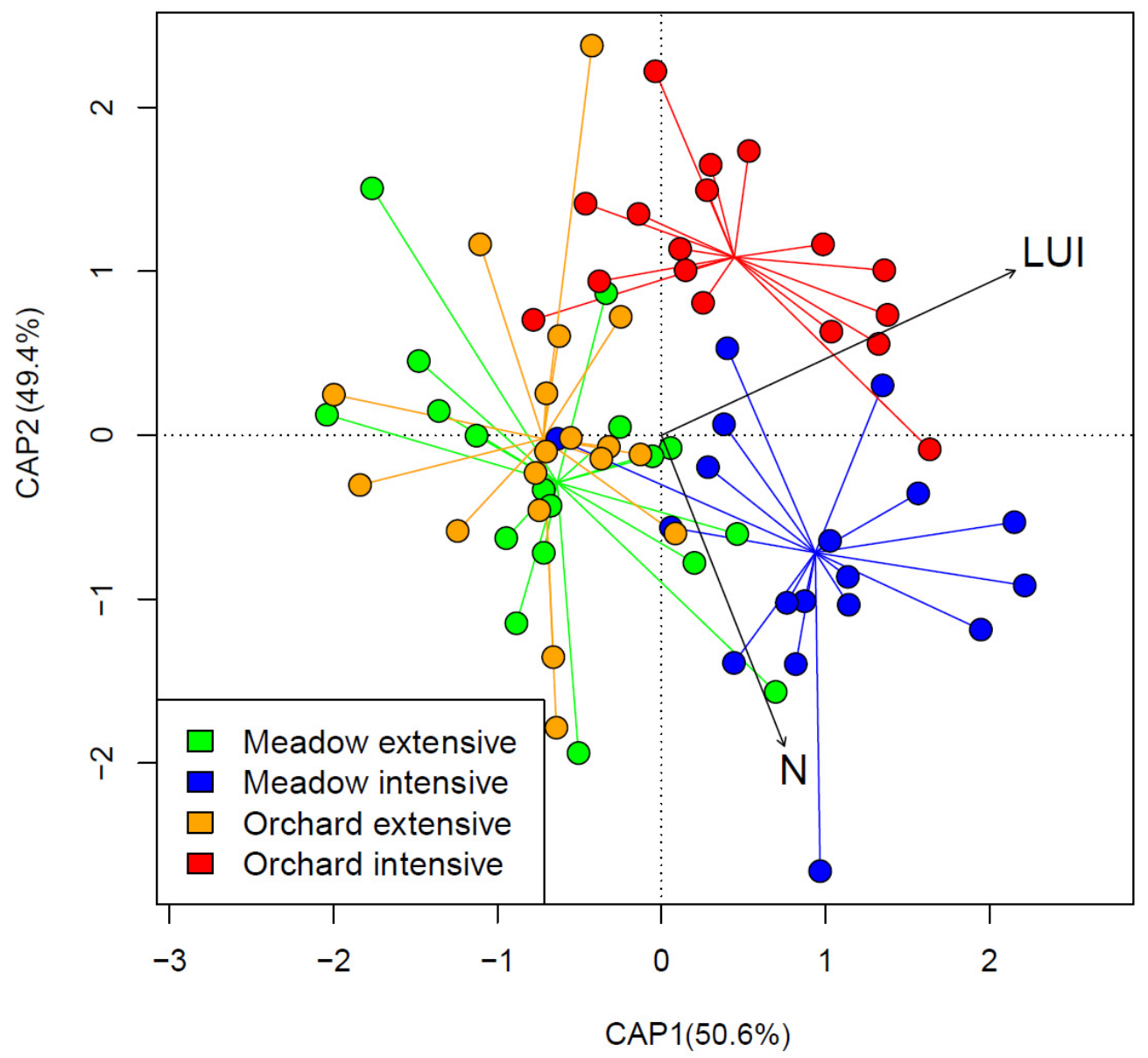

Figure 3. Ordination of the constrained canonical correspondence analysis. Each spot represents one sampling event per site. Colors and spider webs according to the field management type. Spider web centers are the weighted centroids of each management type. 
Regarding site and soil parameters, we found expectable trends and correlations between the single factors (Figure S1). Only non-correlating factors representing site characteristics, physical and chemical parameters as well as management details were selected to be tested in a constrained ordination. The resulting significant parameters in a permutation test where land-use index (LUI; Permutation test: $\left.F_{1,57}=2.93 ; p=0.001\right)$ and soil nitrogen content $\left(\mathrm{N} ;\right.$ Permutation test: $\left.F_{1,57}=2.89 ; p=0.001\right)$ and were implemented in the final ordination (Biplot scores for CAP1: LUI $=0.90 ; \mathrm{N}=0.31$; and for CAP2 LUI $=0.42 ; \mathrm{N}=-0.78$; Figure 3 ). The first constrained axis depicts well the management intensity, separating both the intensely managed fields from the extensive ones. The second axis clearly separates the two intensive management types from each other, contrary to our expectations (Figure 3). We expected intensification to lead to a more simple and similar community as found in several other studies $[17,20,49]$, but this was not the case between orchards and meadows. The differences are apparently directly connected to different management practices. While the recorded management parameters and the sum factor LUI (Table S1) was not able to fully explain these differences, we suspect that (1) the more frequent presence of heavy machinery in intensive orchards (for frequent mowing, working in the fields, picking the fruits) as well as (2) the application of additional chemicals (herbicides and insecticides routinely used in the region: [51]) might further significantly impact the soil community of intensive orchards. The more frequent presence of heavy machines is probably causing soil compaction, limiting the presence of soil macro-invertebrates, and the use of additional chemicals is also known to hamper the soil biodiversity in general [15]. The quantification of both these influences has not been considered in detail in this study, but potentially explains the severe differences between intensive meadows and orchards. Further, $\mathrm{N}$ is highly correlating with the SOM content $(r=0.94)$ and appears to be one factor that differentiates the two intensive forms of management from each other. A decrease in SOM is generally known to be a consequence of soil degradation and a potential threat for soil biodiversity [52], accordingly, richness and diversity of soil invertebrates were lower in intensive orchards where SOM also resulted in lower values. This appears to be true for the intensive orchards but not for the intensive meadows characterized by higher nitrogen and SOM contents even exceeding those of the extensive managed fields, probably due to the higher fertilization with cattle manure.

Concluding, we found a more rich and diverse soil macro-invertebrate community in the extensive forms of the two investigated management types (viz. meadows and orchards). Further, we can state (1) that both extensive management types harbor a strikingly similar soil fauna community, (2) that intensification of land-use leads to a substantial change in these communities, and (3) that this change was profoundly influenced by the type of management.

Supplementary Materials: The following are available online at http://www.mdpi.com/2073-4395/10/6/767/s1, Figure S1: Correlation plot between all parameters. Significant correlations $(p<0.05)$ where marked with a red frame, Figure S2: Species accumulation plots where computed for each season and management type to visualize the sample coverage and species diversity more in detail, Table S1: Table with the site characteristics, Table S2: Table with taxon and site mean abundance and standard deviation for each single field. Data was standardized to $1 \mathrm{~m}^{2}$ of sample and averaged over all nine single subplots sampled per field.

Author Contributions: Conceptualization, E.G. and J.S.; Methodology, E.G., J.S., J.P., F.C. and M.S.; Validation, J.S., F.C. and M.S.; Formal Analysis, E.G. and J.S.; Resources, U.T.; Writing-Original Draft Preparation, E.G.; Writing-Review \& Editing, E.G., F.C., M.S., J.P., U.T. and J.S.; Visualization, E.G.; Supervision, U.T. and J.S.; Project Administration, J.S. All authors have read and agreed to the published version of the manuscript.

Funding: This research was funded by the Provinces of Trentino (IT), South Tyrol (IT) and the State of Tyrol (AT) and is part of the Euregio-EFH (Environment, Food and Health) project. The APC was funded by the Department of Innovation, Research and University of the Autonomous Province of Bozen/Bolzano.

Acknowledgments: We thank the numerous farmers and landowners for giving the permission to sample their fields and providing the essential information on management. We also want to thank Barbara Mosgöller and Tobias F. Weil for help in the field and in the lab. Further, we also want to thank Andreas Hilpold and Georg Niedrist for useful suggestions in site selection. Finally, we want to thank two anonymous reviewer that significantly improved the final manuscript. The authors thank the Department of Innovation, Research and University of the Autonomous Province of Bozen/Bolzano for covering the Open Access publication costs. 
Conflicts of Interest: The authors declare no conflicts of interest.

\section{References}

1. Tilman, D.; Balzer, C.; Hill, J.; Befort, B.L. Global food demand and the sustainable intensification of agriculture. Proc. Natl. Acad. Sci. USA 2011, 108, 20260-20264. [CrossRef] [PubMed]

2. Gonthier, D.J.; Ennis, K.K.; Farinas, S.; Hsieh, H.Y.; Iverson, A.L.; Batáry, P.; Rudolphi, J.; Tscharntke, T.; Cardinale, B.J.; Perfecto, I. Biodiversity conservation in agriculture requires a multi-scale approach. Proc. R. Soc. B Biol. Sci. 2014, 281, 20141358. [CrossRef] [PubMed]

3. Sánchez-Bayo, F.; Wyckhuys, K.A.G. Worldwide decline of the entomofauna: A review of its drivers. Biol. Conserv. 2019, 232, 8-27. [CrossRef]

4. Seibold, S.; Gossner, M.M.; Simons, N.K.; Blüthgen, N.; Müller, J.; Ambarlı, D.; Ammer, C.; Bauhus, J.; Fischer, M.; Habel, J.C.; et al. Arthropod decline in grasslands and forests is associated with landscape-level drivers. Nature 2019, 574, 671-674. [CrossRef] [PubMed]

5. Dainese, M.; Martin, E.A.; Aizen, M.A.; Albrecht, M.; Bartomeus, I.; Bommarco, R.; Carvalheiro, L.G.; Chaplin-Kramer, R.; Gagic, V.; Garibaldi, L.A.; et al. A global synthesis reveals biodiversity-mediated benefits for crop production. Sci. Adv. 2019, 5, 554170. [CrossRef]

6. Hooper, D.U.; Adair, E.C.; Cardinale, B.J.; Byrnes, J.E.K.; Hungate, B.A.; Matulich, K.L.; Gonzalez, A.; Duffy, J.E.; Gamfeldt, L.; Connor, M.I. A global synthesis reveals biodiversity loss as a major driver of ecosystem change. Nature 2012, 486, 105-108. [CrossRef]

7. Tilman, D.; Reich, P.B.; Knops, J.M.H. Biodiversity and ecosystem stability in a decade-long grassland experiment. Nature 2006, 441, 629-632. [CrossRef]

8. FAO. The State of the World's Biodiversity for Food and Agriculture; Bélanger, J., Piling, D., Eds.; FAO Commission on Genetic Resources for Food and Agriculture Assessments: Rome, Italy, 2019; p. 529.

9. CBD Secretariat. The Strategic Plan for Biodiversity 2011-2020 and the Aichi Biodiversity Targets; Secretariat of the Convention on Biological Diversity: Nagoya, Japan, 2010.

10. Cunningham, S.A.; Attwood, S.J.; Bawa, K.S.; Benton, T.G.; Broadhurst, L.M.; Didham, R.K.; McIntyre, S.; Perfecto, I.; Samways, M.J.; Tscharntke, T.; et al. To close the yield-gap while saving biodiversity will require multiple locally relevant strategies. Agric. Ecosyst. Environ. 2013, 173, 20-27. [CrossRef]

11. Bender, S.F.; van der Heijden, M.G.A. Soil biota enhance agricultural sustainability by improving crop yield, nutrient uptake and reducing nitrogen leaching losses. J. Appl. Ecol. 2015, 52, 228-239. [CrossRef]

12. Orgiazzi, A.; Bardgett, R.D.; Barrios, E.; Behan-Pelletier, V.; Briones, M.J.I.; Chotte, J.-L.; De Deyn, G.B.; Eggleton, P.; Fierer, N.; Fraser, T.; et al. Global Soil Biodiversity Atlas; European Commission: Luxembourg, 2016; p. 176.

13. Hedlund, K.; Harris, J. Delivery of soil ecosystem services: From Gaia to genes. In Soil Ecology and Ecosystem Services; Wall, D.H., Bardgett, R.D., Behan-Pelletier, V., Herrick, J.E., Jones, T.H., Ritz, K., Six, J., Strong, D.R., van der Putten, W., Eds.; Oxford University Press: Oxford, UK, 2012; pp. 98-110.

14. Veresoglou, S.D.; Halley, J.M.; Rillig, M.C. Extinction risk of soil biota. Nat. Commun. 2015, 6, 8862. [CrossRef]

15. Nielsen, U.N. Soil Fauna Assemblages; Cambridge University Press: Cambridge, UK, 2019; p. 365.

16. Eggleton, P.; Vanbergen, A.J.; Jones, D.T.; Lambert, M.C.; Rockett, C.; Hammond, P.M.; Beccaloni, J.; Marriott, D.; Ross, E.; Giusti, A. Assemblages of soil macrofauna across a Scottish land-use intensification gradient: Influences of habitat quality, heterogeneity and area. J. Appl. Ecol. 2005, 42, 1153-1164. [CrossRef]

17. Tsiafouli, M.A.; Thébault, E.; Sgardelis, S.P.; de Ruiter, P.C.; van der Putten, W.H.; Birkhofer, K.; Hemerik, L.; de Vries, F.T.; Bardgett, R.D.; Brady, M.V.; et al. Intensive agriculture reduces soil biodiversity across Europe. Glob. Chang. Biol. 2015, 21, 973-985. [CrossRef] [PubMed]

18. Bai, Z.; Caspari, T.; Gonzalez, M.R.; Batjes, N.H.; Mäder, P.; Bünemann, E.K.; de Goede, R.; Brussaard, L.; $\mathrm{Xu}$, M.; Ferreira, C.S.S.; et al. Effects of agricultural management practices on soil quality: A review of long-term experiments for Europe and China. Agric. Ecosyst. Environ. 2018, 265, 1-7. [CrossRef]

19. Culman, S.W.; Young-Mathews, A.; Hollander, A.D.; Ferris, H.; Sánchez-Moreno, S.; O’Geen, A.T.; Jackson, L.E. Biodiversity is associated with indicators of soil ecosystem functions over a landscape gradient of agricultural intensification. Landsc. Ecol. 2010, 25, 1333-1348. [CrossRef] 
20. De Vries, F.T.; Thebault, E.; Liiri, M.; Birkhofer, K.; Tsiafouli, M.A.; Bjornlund, L.; Bracht Jorgensen, H.; Brady, M.V.; Christensen, S.; de Ruiter, P.C.; et al. Soil food web properties explain ecosystem services across European land use systems. Proc. Natl. Acad. Sci. USA 2013, 110, 14296-14301. [CrossRef]

21. Rüdisser, J.; Tasser, E.; Peham, T.; Meyer, E.; Tappeiner, U. The dark side of biodiversity: Spatial application of the biological soil quality indicator (BSQ). Ecol. Indic. 2015, 53, 240-246. [CrossRef]

22. Birkhofer, K.; Dietrich, C.; John, K.; Schorpp, Q.; Zaitsev, A.S.; Wolters, V. Regional conditions and land-use alter the potential contribution of soil arthropods to ecosystem services in grasslands. Front. Ecol. Evol. 2016, 3, 50. [CrossRef]

23. Lal, R. Restoring soil quality to mitigate soil degradation. Sustainability 2015, 7, 5875-5895. [CrossRef]

24. Parisi, V.; Menta, C.; Gardi, C.; Jacomini, C.; Mozzanica, E. Microarthropod communities as a tool to assess soil quality and biodiversity: A new approach in Italy. Agric. Ecosyst. Environ. 2005, 105, 323-333. [CrossRef]

25. Lavelle, P.; Decaëns, T.; Aubert, M.; Barot, S.; Blouin, M.; Bureau, F.; Margerie, P.; Mora, P.; Rossi, J.P. Soil invertebrates and ecosystem services. Eur. J. Soil Biol. 2006, 42, 3-15. [CrossRef]

26. Smith, J.; Potts, S.; Eggleton, P. The value of sown grass margins for enhancing soil macrofaunal biodiversity in arable systems. Agric. Ecosyst. Environ. 2008, 127, 119-125. [CrossRef]

27. Nuria, R.; Jérôme, M.; Léonide, C.; Christine, R.; Gérard, H.; Etienne, I.; Patrick, L. IBQS: A synthetic index of soil quality based on soil macro-invertebrate communities. Soil Biol. Biochem. 2011, 43, 2032-2045. [CrossRef]

28. Barrios, E.; Sileshi, G.W.; Shepherd, K.; Sinclair, F. Agroforestry and soil health: Linking trees, soil biota, and ecosystem services. In Soil Ecology and Ecosystem Services; Wall, D.H., Bardgett, R.D., Behan-Pelletier, V., Herrick, J.E., Jones, T.H., Ritz, K., Six, J., Strong, D.R., van der Putten, W., Eds.; Oxford University Press: Oxford, UK, 2012; pp. 315-330.

29. Kuttner, M.; Essl, F.; Peterseil, J.; Dullinger, S.; Rabitsch, W.; Schindler, S.; Hülber, K.; Gattringer, A.; Moser, D. A new high-resolution habitat distribution map for Austria, Liechtenstein, southern Germany, South Tyrol and Switzerland. J. Protec. Mt. Areas Res. Manag. 2015, 7, 18-29. [CrossRef]

30. Unterluggauer, P. Traditionell und intensiv bewirtschaftete wiesen in südtirol-ihre vegetation als indikator für die bewirtschaftungsintensität vegetation types as estimates of the management intensity. Tuexenia 2016, $36,37-62$.

31. Hilpold, A.; Seeber, J.; Fontana, V.; Niedrist, G.; Steinwandter, M.; Tasser, E.; Tappeiner, U. Decline of rare and specialized species across multiple taxonomic groups after grassland intensification and abandonment. Biodivers. Conserv. 2018, 14, 3729-3744. [CrossRef]

32. Egarter Vigl, L.; Schirpke, U.; Tasser, E.; Tappeiner, U. Linking long-term landscape dynamics to the multiple interactions among ecosystem services in the European Alps. Landsc. Ecol. 2016, 31, 1903-1918. [CrossRef]

33. Blüthgen, N.; Dormann, C.F.; Prati, D.; Klaus, V.H.; Kleinebecker, T.; Hölzel, N.; Alt, F.; Boch, S.; Gockel, S.; Hemp, A.; et al. A quantitative index of land-use intensity in grasslands: Integrating mowing, grazing and fertilization. Basic Appl. Ecol. 2012, 13, 207-220. [CrossRef]

34. Fischer, M.; Bossdorf, O.; Gockel, S.; Hänsel, F.; Hemp, A.; Hessenmöller, D.; Korte, G.; Nieschulze, J.; Pfeiffer, S.; Prati, D.; et al. Implementing large-scale and long-term functional biodiversity research: The biodiversity exploratories. Basic Appl. Ecol. 2010, 11, 473-485. [CrossRef]

35. Durner, W.; Iden, S.C.; von Unold, G. The integral suspension pressure method (ISP) for precise particle-size analysis by gravitational sedimentation. Water Resour. Res. 2017, 53, 33-48. [CrossRef]

36. Kempson, D.; Lloyd, M.; Ghelardi, R. A new extractor for woodland litter. Pedobiologia 1963, 3, 1-21.

37. Schaefer, M. Brohmer-Fauna von Deutschland: Ein Bestimmungsbuch Unserer Heimischen Tierwelt; Quelle \& Meyer Verlag: Wiebelsheim, Germany, 2017; p. 765.

38. Klausnitzer, B.; Hannemann, H.-J.; Senglaub, K. Exkursionsfauna von Deutschland: Band 2 Wirbellose: Insekten; Springer: Dresden, Germany, 2011; p. 937.

39. Hannemann, H.-J.; Klausnitzer, B.; Senglaub, K. Stresemann-Exkursionsfauna von Deutschland. Band 1: Wirbellose (Ohne Insekten); Springer: Dresden, Germany, 2019; p. 673.

40. Smith, K.G.V. An introduction to the immature stages of British flies: Diptera larvae, with notes on eggs, Puparia and Pupae. Handb. Identif. Br. Insects 1989, 10, 280.

41. Latella, L.; Gobbi, M. La Fauna del Suolo: Tassonomia, Ecologia e Metodi di Studio dei Principali Gruppi di Invertebrati Terrestri Italiani; Quaderni del Museo delle Scienze: Trento, Italy, 2015; p. 205. 
42. De Jong, Y.; Verbeek, M.; Michelsen, V.; de Bjørn, P.P.; Los, W.; Steeman, F.; Bailly, N.; Basire, C.; Chylarecki, P.; Stloukal, E.; et al. Fauna Europaea-All European animal species on the web. Biodivers. Data J. 2014, 2, e4034. [CrossRef] [PubMed]

43. Hsieh, T.C.; Ma, K.H.; Chao, A. iNEXT: An R package for rarefaction and extrapolation of species diversity (hill numbers). Methods Ecol. Evol. 2016, 7, 1451-1456. [CrossRef]

44. Oksanen, J.; Blanchet, F.G.; Friendly, M.; Kindt, R.; Legendre, P.; McGlinn, D.; Minchin, P.R.; O'Hara, R.B.; Simpson, G.L.; Solymos, P.; et al. Vegan: Community Ecology Package. R Package Version 2.5-2. Available online: https://CRAN.R-project.org/package=vegan (accessed on 17 April 2020).

45. Team, R.C. R: A Language and Environment for Statistical Computing; R Foundation for Statistical Computing: Vienna, Austria, 2017.

46. Wickham, H. ggplot2: Elegant Graphics for Data Analysis, 2nd ed.; Springer: New York, NY, USA, 2016 ; p. 260.

47. Wei, T.; Simko, V.; Levy, M.; Xie, Y.; Jin, Y.; Zemla, J. Package "corrplot". Statistician 2017, 56, 316-324.

48. Simons, N.K.; Weisser, W.W.; Gossner, M.M. Multi-taxa approach shows consistent shifts in arthropod functional traits along grassland land-use intensity gradient. Ecology 2016, 97, 754-764. [CrossRef] [PubMed]

49. Mazzia, C.; Pasquet, A.; Caro, G.; Thénard, J.; Cornic, J.F.; Hedde, M.; Capowiez, Y. The impact of management strategies in apple orchards on the structural and functional diversity of epigeal spiders. Ecotoxicology 2015, 24, 616-625. [CrossRef]

50. Paoletti, M.G.; Schweigl, U.; Favretto, M.R. Soil macroinvertebrates, heavy metals and organochlorines in low and high input apple orchards and a coppiced woodland. Pedobiologia 1995, 39, 20-33.

51. Dalla Via, J.; Mantinger, H. Die Landwirtschaftliche forschung im obstbau südtirols: Entwicklung und ausblick. Erwerbs-Obstbau 2012, 54, 83-115. [CrossRef]

52. Gardi, C.; Jeffery, S.; Saltelli, A. An estimate of potential threats levels to soil biodiversity in EU. Glob. Chang. Biol. 2013, 19, 1538-1548. [CrossRef]

(C) 2020 by the authors. Licensee MDPI, Basel, Switzerland. This article is an open access article distributed under the terms and conditions of the Creative Commons Attribution (CC BY) license (http://creativecommons.org/licenses/by/4.0/). 